\title{
ELK-CATTLE INTERACTIONS \\ IN CALVING AREAS
}

John R. Sauer and Mark S. Boyce

Department of Zoology and Physiology

University of Wyoming

\section{Objectives}

Elk (Cervus canadensis nelsoni) in northwestern Wyoming tend to calve in open sagebrush habitats. In Jackson Hole the portion of Grand Teton National Park east of Elk Ranch Reservoir has been described as a traditional calving ground for elk (Anderson 1958). Cattle are grazed in this area starting June 1 , at the peak of the elk calving period. In May 1978 a study was begun to determine if the cattle and associated human disturbances had a detrimental effect on the elk. Elk use of the area was found to significatly decrease after the cattle entered the area. (Boyce and Sauer 1979). Field work this year was designed to substantiate the conclusions from last year's observations and provide more information on how the elk respond to the presence of cattle on their preferred calving habitat.

Methods

An $8 \mathrm{~km}$ transect was walked starting at dawn through the study area east of Elk Ranch Reservoir. For each group of elk that was observed, data were collected on total number of elk, sex and age of individuals, vegetation type, visibility, individual distances and activities when first observed. These morning censuses began on May 20 and continued through June 12. Observations were made throughout the day to determine variation in habitat use on a daily basis.

The hypothesis that the number of elk in the study area (as determined by the morning census) decreased significantly after cattle were introduced was tested using a t-test. The other observed attributes (habitat use, activity, etc.) will be stratified as to time of day and also tested to see if the introduction of cattle to the calving area significantly changed the behavior of the elk.

\section{Results}

Total elk numbers within the study area decreased significantly ( $p<.01$ ) after the cattle were introduced. Disturbances in Teton National Forest on June 11 and 12 caused the elk to flood back into the study area. These two days were eliminated from the analysis. Data on elk habitat use, individual distance, activity and visibility are currently being placed in a format for statistical analysis. Inspection of the data 
indicate, however, that the presence of cattle does not have a great effect on these variables. Tenatively then, it appears that the presence of cattle in the calving area significantly decreases the number of elk in the area, but the remaining elk do not modify their behavior in response to the cattle.

\section{Discussion}

Field observations from both 1978 and 1979 indicate that elk use of preferred calving habitat significantly decreases when cattle are introduced into the area. The elk that remain on the calving grounds after the cattle are introduced do not seem to change their behavior in response to the presence of the cattle. These elk, however, are subject to increased human disturbance associated with the cattle.

Exclusion of the elk from calving grounds during the calving period could force them to calve in sub-optimal habitat, possibly causing increased stress on the calves and making them more visible and vulnerable to predation by black bears (Ursus americanus) and coyote (Canis latrans) (Schlegel 1976). Increased disturbance of cow elk by cattle and associated human activity cause the elk to be flushed more frequently than undisturbed $e l k$, and calves that are too young to run with the cows are left hidden in the sagebrush (Pers. obs.). These calves have a higher probability of either being preyed on by the abundant coyote population in the area or of being deserted by their dams than do calves whose dams are nearby (McCullough 1969). Increased frequency of calf desertion when the dams are disturbed has been demonstrated for white tailed deer (Odocoileus virginianus) by White et al (1972).

It is difficult to determine whether the noted decrease in elk numbers is due to the cattle and not to some phenological or behavorial characteristic of the elk. However, the increase in the number of elk on June 11 and 12 in response to human disturbance in the adjacent national forest lands indicate that elk were present in the surrounding area. The decrease in elk use is therefore probably not an artifact of the migratory patterns of the elk. The elk were still present, but were not using the area.

\section{Literature Cited}

Anderson, C.C. 1958 The elk of Jackson Hole. Bull. 10. Wyo. Game and Fish Comm., Cheyenne 184pp.

Boyce, M.S. and J.R. Sauer. 1979. Elk distribution and behavior in calving areas. pp. 15-18 IN University of Wyoming National Park Service Research Center Second Annual Report, 1978,

McCullough,D.R. 1969. The tulc elk: its history, behavior, and ecology. Univ. of Calif. Publ. Aool. 88: 209pp. 
Schlegel, M. 1976. Factors affecting calf elk survival in north-central Idaho..A progress report. Proc. West/ Assoc. State Game and Fish Commissioners 56:347-355.

White, M. F.F. Knowlton and W,C. Glazener. 1972. Effects of damnewborn fawn behavior on capture and mortality. J. Wildl. Manage 36:897-906. 